Provided for non-commercial research and education use. Not for reproduction, distribution or commercial use.

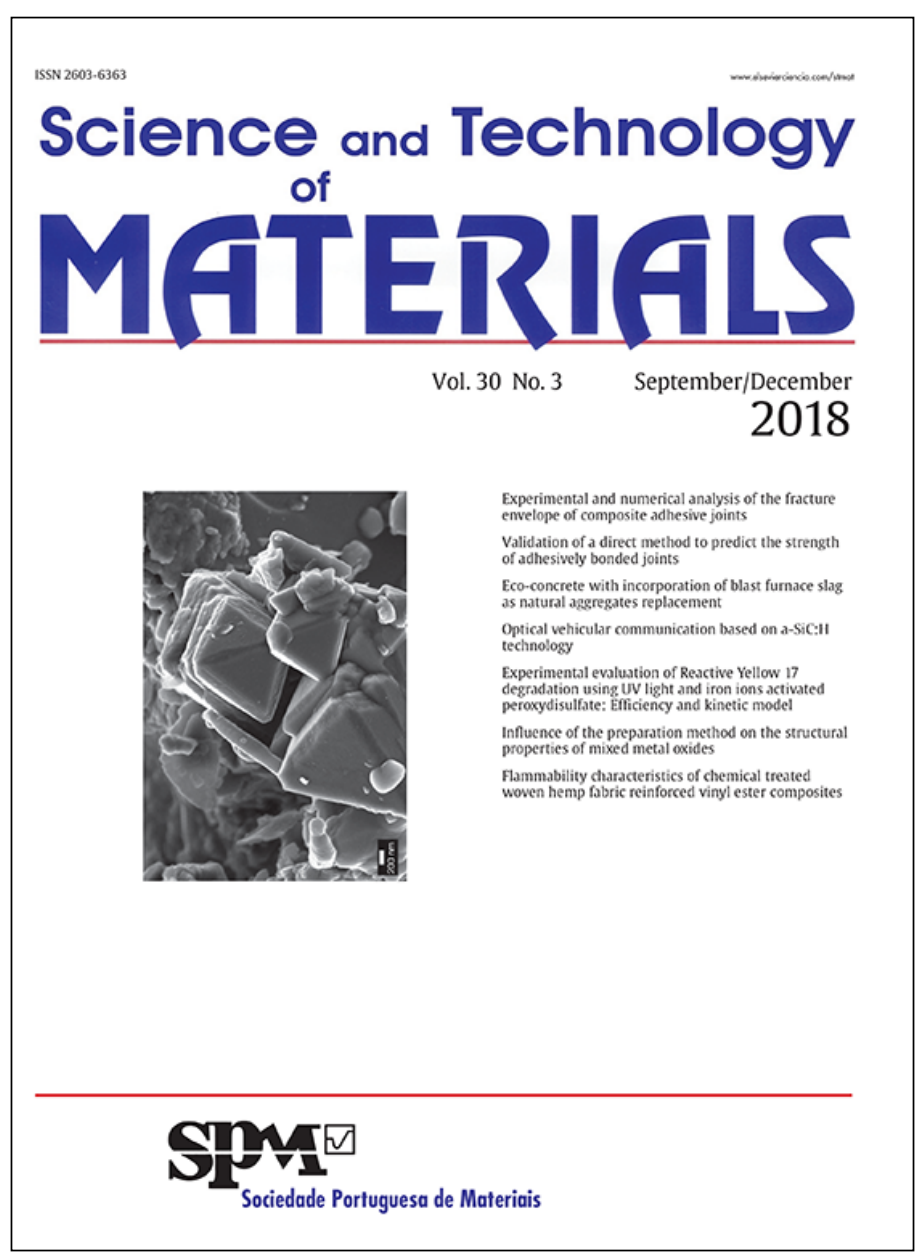

This article appeared in a journal published by Elsevier. The attached copy is furnished to the author for internal non-commercial research and education use, including for instruction at the author's institution and sharing with colleagues.

Other uses, including reproduction and distribution, or selling or licensing copies, or posting to personal, institutional or third party websites are prohibited.

In most cases authors are permitted to post their version of the article (e.g. in Word or Tex form) to their personal website or institutional repository. Authors requiring further information regarding Elsevier's archiving and manuscript policies are encouraged to visit:

http://www.elsevier.com/authorsrights 


\title{
Eco-concrete with incorporation of blast furnace slag as natural aggregates replacement
}

\author{
M. Senani ${ }^{\text {a }}$, N. Ferhoune ${ }^{\text {b,* }}$, A. Guettala ${ }^{a}$, J.B. Aguiar ${ }^{c}$ \\ ${ }^{a}$ University of Mohamed Khider, Biskra 07000, Algeria \\ ${ }^{\mathrm{b}}$ University of larbi ben m'hidi, Oum el bouaghi 04000, Algeria \\ ${ }^{\mathrm{c}}$ University of Minho, Guimarães 4704-553, Portugal
}

Received 26 April 2017; accepted 11 December 2017

\begin{abstract}
This study focused on studying the possibility of using concrete with incorporation of slag from blast furnace in the filling of short steel columns. The natural sand was totally or partially replaced by the sand slag in the composition of the concrete. The characterization of these concretes was made based on their physical properties (apparent and specific densities, porosity and fineness modulus), mechanical properties (compressive and tensile strengths) and the microstructure analysis by scanning electron microscopy (SEM). The comparison with the conventional concrete was made. The experimental results show that the percentages of sand slag on the concrete composition have an important effect on the enhancement of the mechanical proprieties. The comparison of the different determined characteristics shows the benefits of the use of sand slag in the concrete composition compared with the conventional concrete.
\end{abstract}

(C) 2018 Sociedade Portuguesa de Materiais (SPM). Published by Elsevier España, S.L.U. All rights reserved.

Keywords: Slag filler; Concrete; Microstructure; Physical performance; Mechanical performance

\section{Introduction}

There are environmental problems due to the excessive use of natural resources to produce construction materials, like concrete. The use of local resources and the search for a new range of building materials, can solve at least part of the problems. In this context, the debate opens on the formulation of new concretes, which would incorporate an abundant and untapped resource, presenting similar characteristics to the conventional concrete [1]. The incorporation of granulated blast furnace slag can lower the cement content and be an alternative to the rigid economic structure, replacing conventional aggregates by slag aggregates, accessible at lower costs. Compared to conventional concrete, the implementation of this concrete does not have any particular problems [2-5]. The mechanical strengths can be enhanced, provided that the sand replacement ratio is lower than 30\% [6]. Also, the use of copper slag aggregate compared with limestone

\footnotetext{
* Corresponding author.

E-mail address: ferhoune.noureddine@gmail.com (N. Ferhoune).
}

aggregate increased the concrete mechanical strengths [7]. The use of an industrial waste, as a substitute material, helps to save large amounts of natural resources and to protect the environment. However, it is important the consideration of the transport impact associated to the use of the industrial waste [8].

Few studies have been made on the characterization of this concrete [9-16]. In this study, the complete replacement of conventional aggregates by slag sand, was evaluated. The different physical and mechanical properties, and the microstructure of the concretes, were determined.

\section{Materials characterization}

\subsection{Cement and water}

The cement used in this study was the commercial Portland (CEMII) class 42.5 from cement factory of Hadjar Elsoud Skida, Algeria. It is consistent with the Algerian standard NA422 [17]. It contains a granulated slag addition of blast furnace in the order of $20 \%$ and $5 \%$ of gypsum. The chemical and mineralogical 
Table 1

Chemical and mineralogical compositions of the cement.

\begin{tabular}{lcllc}
\hline \multicolumn{2}{c}{ Chemical composition } & & \multicolumn{2}{c}{ Mineralogical composition } \\
\cline { 5 - 5 } Substances & Percentage & & Minerals & Percentage \\
\hline $\mathrm{CaO}$ & 58.59 & & $\mathrm{C}_{3} \mathrm{~S}$ & $50-65$ \\
$\mathrm{Al}_{2} \mathrm{O}_{3}$ & 6.58 & & $\mathrm{C}_{2} \mathrm{~S}$ & $10-25$ \\
$\mathrm{SiO}_{2}$ & 24.92 & & $\mathrm{C}_{3} \mathrm{~A}$ & $9-12$ \\
$\mathrm{Fe}_{2} \mathrm{O}_{3}$ & 3.65 & & $\mathrm{C}_{4} \mathrm{AF}$ & $7-11$ \\
$\mathrm{MgO}^{2}$ & 1.21 & & \\
$\mathrm{Na}_{2} \mathrm{O}$ & 0.08 & & & \\
$\mathrm{~K}_{2} \mathrm{O}$ & 0.85 & & & \\
$\mathrm{Cl}^{-}$ & 0.00 & & \\
$\mathrm{SO}_{3}$ & 2.17 & & \\
Fire loss & 1.70 & & \\
\hline
\end{tabular}

Table 2

Physical properties of the cement.

\begin{tabular}{lc}
\hline Characteristics & Cement type CEMII/A-42.5 \\
\hline Apparent density $\left(\mathrm{kg} / \mathrm{m}^{3}\right)$ & 1057 \\
Specific density $\left(\mathrm{kg} / \mathrm{m}^{3}\right)$ & 3100 \\
Normal consistency $(\%)$ & 29 \\
Initial setting time $(\mathrm{min})$ & 154 \\
Blaine specific surface $\left(\mathrm{cm}^{2} / \mathrm{g}\right)$ & 3480 \\
Fineness of grind $(\%)$ & 9.6 \\
\hline
\end{tabular}

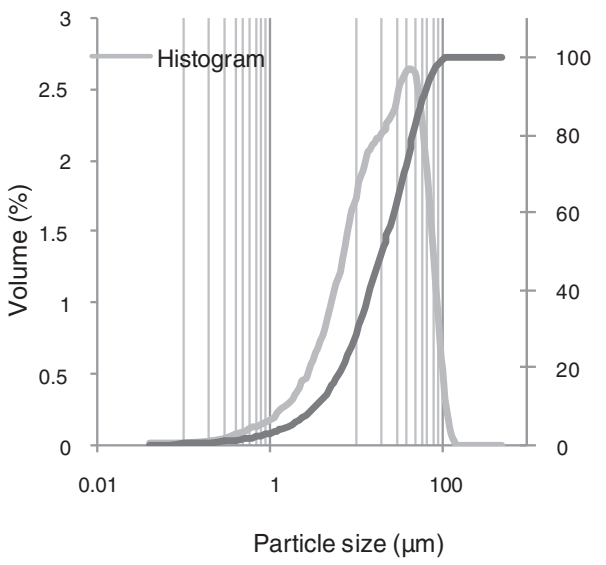

Fig. 1. Grading curves of the cement.

compositions and the physical characterization of the cement are presented in Tables 1 and 2. The grading curve of the cement is given in Fig. 1. Tap water was used in the composition of the concretes. The water was at a temperature of $20 \pm 2{ }^{\circ} \mathrm{C}$. Its quality conforms to the requirements of the standard NFP 18-404 [18].

\subsection{Sand}

The used natural sand $(0 / 2.5 \mathrm{~mm})$ is from Tebessa quarry, Algeria, and the slag sand $(0 / 3.15 \mathrm{~mm})$ is from blast furnace of the El Hadjar steel complex, Algeria. The physical properties of the sands are presented in Table 3. The chemical compositions were determined with fluorescence X-ray test with Panalytical Philips X'unique II machine. The results are presented in
Table 3

Physical properties of the sands.

\begin{tabular}{lcc}
\hline Characteristics & Dune sand $(0 / 2.5 \mathrm{~mm})$ & Sand slag $(0 / 3.15 \mathrm{~mm})$ \\
\hline Apparent density $\left(\mathrm{kg} / \mathrm{m}^{3}\right)$ & 1610 & 1570 \\
Specific density $\left(\mathrm{kg} / \mathrm{m}^{3}\right)$ & 2680 & 2630 \\
Porosity (\%) & 40 & 41 \\
Fineness modulus (M.F.) & 2.5 & 2.46 \\
Water content (\%) & - & 0.35 \\
Sand equivalent ES (\%) & 80.52 & 83.95 \\
\hline
\end{tabular}

Table 4

Chemical compositions (\%) of the different sands and filler.

\begin{tabular}{llcc}
\hline Components (oxides) & Natural sand & Sand slag & Filler slag \\
\hline $\mathrm{Al}_{2} \mathrm{O}_{3}$ & 1.70 & 9.02 & 9.25 \\
$\mathrm{BaO}$ & 0.02 & 0.57 & 0.46 \\
$\mathrm{CaO}$ & 0.51 & 39.8 & 40.5 \\
$\mathrm{Cr}_{2} \mathrm{O}_{3}$ & 0.09 & 0.03 & 0.03 \\
$\mathrm{CuO}$ & 0.01 & 0.01 & 0.01 \\
$\mathrm{Fe}_{2} \mathrm{O}_{3}$ & 0.66 & 1.63 & 0.48 \\
$\mathrm{~K}_{2} \mathrm{O}$ & 0.45 & 0.38 & 0.46 \\
$\mathrm{MnO}$ & 0.01 & 1.32 & 1.47 \\
$\mathrm{MgO}$ & - & 3.13 & 4.08 \\
$\mathrm{NiO}$ & 0.01 & - & 0.01 \\
$\mathrm{SiO}$ & 96.5 & 42.2 & 41.5 \\
$\mathrm{SrO}_{\mathrm{TiO}}$ & $<0.01$ & 0.22 & 0.23 \\
$\mathrm{SO}_{3}$ & 0.04 & 0.10 & 0.09 \\
$\mathrm{ZrO}_{2}$ & - & 1.54 & 1.44 \\
\hline
\end{tabular}

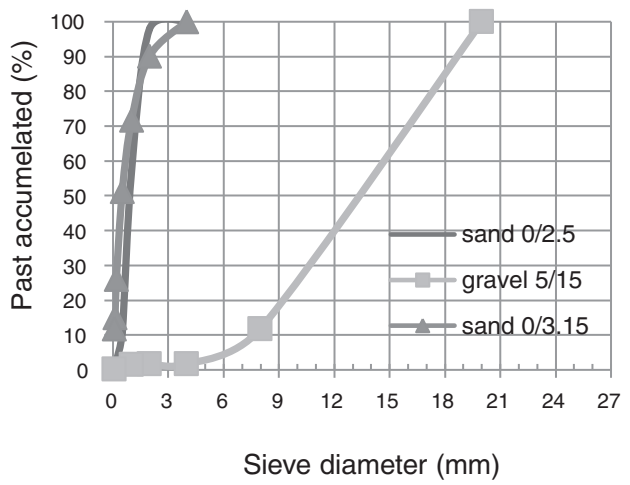

Fig. 2. Grading curves of aggregates.

Table 4. All properties were measured following the standards NF P18-553 [19], NF P18-555 [20], NF EN 933-8 [21] and NF P18-560 [22]. The grading curves of the different sands are given in Fig. 2.

\subsection{Coarse aggregates}

The coarse aggregate used is composed with fractions of crushed stone $(5 / 15 \mathrm{~mm})$ from the Souk Ahras region, Algeria. The apparent density measured is $1300.0 \mathrm{~kg} / \mathrm{m}^{3}$, the specific density is $2500 \mathrm{~kg} / \mathrm{m}^{3}$ and the Los Angeles coefficient is equal to $23.04 \%$ (hard). These properties were measured by NF P18560 [22], NF P18-554 [23] and NF P18-573 [24]. The grading 
Table 5

Physical properties of the coarse aggregates.

\begin{tabular}{lc}
\hline Characteristics & Coarse aggregates $5 / 15 \mathrm{~mm}$ \\
\hline Apparent density $\left(\mathrm{kg} / \mathrm{m}^{3}\right)$ & 1300 \\
Specific density $\left(\mathrm{kg} / \mathrm{m}^{3}\right)$ & 2500 \\
Porosity $(\%)$ & 48 \\
Water content $(\%)$ & 0.79 \\
Absorption coefficient $(\%)$ & 2.55
\end{tabular}

Table 6

Physical properties of the filler slag.

\begin{tabular}{ll}
\hline Characteristics & Filler slag \\
\hline Bulk density $\left(\mathrm{kg} / \mathrm{m}^{3}\right)$ & 1275 \\
Absolute density $\left(\mathrm{kg} / \mathrm{m}^{3}\right)$ & 2955.3 \\
Fineness $\left(\mathrm{cm}^{2} / \mathrm{g}\right)$ & 5501.9 \\
\hline
\end{tabular}

curve of the coarse aggregate is given in Fig. 2. The physical properties of the coarse aggregate are shown in Table 5.

\subsection{Mineral addition}

In this study, granulated slag filler was obtained primarily by milling by-products of the steel industry blast furnace of ElHadjar. The glass structure, with a rate of $97 \%$, confirms that it has low hydraulic power. The slag was comminuted to fineness higher than that of the cement. The chemical composition and the physical properties of the addition are shown in Tables 4 and 6.

\subsection{Super plasticizer}

In this study, a high water reducer super plasticizer based in an acrylic copolymer and named SIKA VISCOCRETETEMPO 12 was used. The super plasticizer respected the exigencies of the standard NFEN934-2 [25]. The technical characteristics of the admixture are presented in Table 7.
Table 7

Technical characteristics of the super plasticizer.

\begin{tabular}{lc}
\hline Characteristics & Adjuvant TEMPO12 \\
\hline Density $\left(\mathrm{kg} / \mathrm{m}^{3}\right)$ & $1.06 \pm 0.01$ \\
$\mathrm{pH}$ & $6 \pm 1$ \\
Dry extract & $30.2 \pm 13 \%$ \\
Ion content $\mathrm{Cl}^{-}$ & $\leq 0.1 \%$ \\
$\mathrm{Na}_{2} \mathrm{O}$ content eq. & $\leq 1.0 \%$ \\
Range of use & $0.2-3 \%$ \\
\hline
\end{tabular}

\section{Experimental program}

\subsection{Specimens preparation}

In this study, 72 specimens were prepared involving four types of concretes, for all tests. Concrete mixes containing either natural or slag sands were studied and compared. Four different mix designs were investigated for the concretes with natural and slag sand (Fig. 3). The first one was a control mix and did not contain any granulated blast furnace slag. It is designated by BO. Two of the mixes contained slag sand replacing $100 \%$ of the natural sand which are designated by BSI and BSII, with different percentages of filler slag and the use of super plasticizer. The last one contained $28 \%$ of natural sand and $72 \%$ of slag sand which is designated by BSIII. The complete proportions for the mixes BO, BSI, BSII and BSIII are given in Table 8.

Table 8

Mix proportions and workability of the concretes.

\begin{tabular}{llcccc}
\hline Materials & Unit & BO & BSI & BSII & BSIII \\
\hline Cement CPJ 42.5 & $\mathrm{kg} / \mathrm{m}^{3}$ & 350 & 300 & 300 & 300 \\
w/c calculated & - & 0.5 & 0.81 & 0.6 & 0.61 \\
w/c real & - & 0.58 & 0.88 & 0.7 & 0.88 \\
Sand dune 0/2.5 & $\mathrm{kg} / \mathrm{m}^{3}$ & 737 & - & - & 500 \\
Sand slag 0/3.15 & $\mathrm{kg} / \mathrm{m}^{3}$ & - & 1540 & 1530 & 1275 \\
Coarse aggregates 5/15 & $\mathrm{kg} / \mathrm{m}^{3}$ & 1075.3 & - & - & - \\
Slag filler & $\mathrm{kg} / \mathrm{m}^{3}$ & - & 200 & 78 & 200 \\
Super plasticizer & $\mathrm{kg} / \mathrm{m}^{3}$ & - & - & 6 & - \\
Slump & $\mathrm{cm}$ & 6 & 6 & 6 & 6 \\
\hline
\end{tabular}

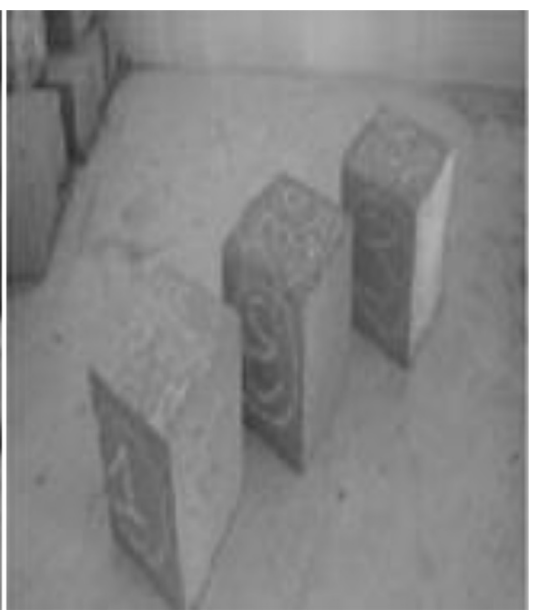

Fig. 3. Concrete specimens. 


\section{Results and discussion}

\subsection{Concrete slump}

The slump test was performed in accordance with the standard NFP18-451 [26]. The four types of concrete BO, BSI, BSII and BSIII were formulated with a plastic consistency, with a slump of $60 \pm 1 \mathrm{~mm}$. Fig. 4 shows the different results of the real and calculated water/cement ratios of the studied four types of concrete. The water/cement ratio increases with the amount of slag sand due to the increase of the fine particles and the cavities found in the slag sand particles [27]. However, the concrete with super plasticizer presented a lower water/cement ratio because the dispersant super plasticizer action increases the workability of concrete, increasing the slump.

\subsection{Density}

The density was determined using the standard NFEN 123506 [28]. The results are shown in Fig. 5. As for a conventional concrete, the density of the slag sand concrete depends on its formulation. The results of the density show that the compactness is improved with the increase in fines content added to the mixtures BSI and BSIII. The increase in compactness can be explained by the fact that the fine additions lodge in the intergranular voids of the sand.

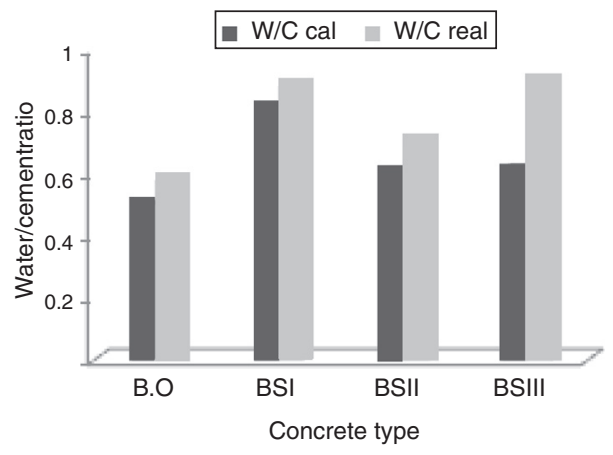

Fig. 4. Variation of the water/cement ratios for different concrete types.

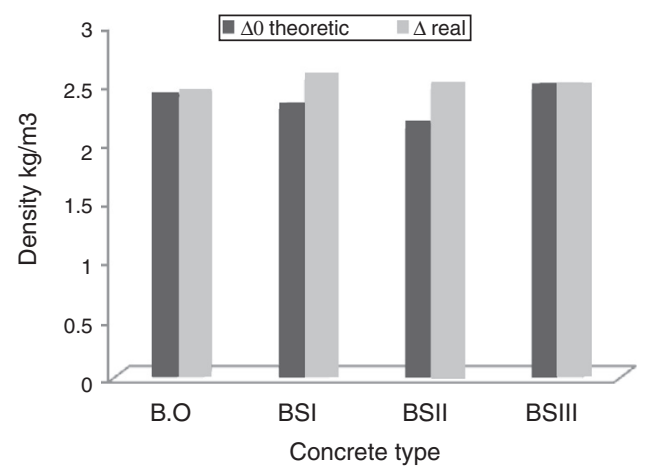

Fig. 5. Density of the different concretes.

\subsection{Microstructure characterization}

Micro structural analyses of the concrete specimens were carried out by scanning electron microscope (SEM). The microstructure and interface between the aggregate particles and the cement matrix of the control concrete and the concrete containing $100 \%$ of crystallized slag sand were examined on the crushed sample surfaces.

The photos of Figs. 6-9 show the presence of micro pores visible at the level of the cement matrix and which differs from one concrete to the other. This is explained by the difference in the granular distribution. The figures also illustrate the good compactness of the two concretes used in this study, with the presence of a very small micro porosity.

In Figs. 6 and 7, certain heterogeneity of the matrix can be observed which is explained by the presence of a high number of micro pores and a lower bond aggregate-matrix. This can be better seen at a higher magnification.

The BSII microstructure with granulated slag filler appeared to be fairly compact (Figs. 8 and 9), with the presence of some iron-rich elements (white color) and with the texture of the hydrates becoming more compact and homogeneous. This is mainly due to the involvement of the granulated slag in the secondary HSC formation process.

The bonding between sand and cement paste at the interface (no tearing) is very strong, as well as the fineness of the component in the immediate vicinity of the sand (Figs. 8 and 9). This state of the microstructure approves the pozzolanic or reactive character of the granulated slag filler.

\subsection{Compressive strengths}

The compressive strengths were determined with 12 cubic samples of concrete with dimensions $150 \mathrm{~mm} \times 150 \mathrm{~mm} \times 150 \mathrm{~mm}$. The compressive strengths of the concrete were obtained at different conservation days, using a $500 \mathrm{kN}$ compressive hydraulic testing machine. The compression tests were conducted in accordance with the standard NF P 18-406 [29]. For the four types of concrete the compressive strength increased with the conservation time (Fig. 10). The results also show that the compressive strength of concrete BSII is higher than that of the other concretes (BO, BSI and BSIII). This can be explained by the porosity decrease showed by the micro structural analysis. For this result also contributed the use of super plasticizer and the pozzolanic effect evidenced by the granulated slag filler.

\subsection{Tensile strength}

The tensile strength was determined using the standard BS 1881 [30]. The splitting tensile strengths of the concrete mixes are compared at different curing ages, 7 and 28 days (Fig. 11). The results show that the tensile strengths largest recorded values are that of the concretes BSI and BSII, whose natural sand was completely replaced by the slag sand. The composition of these concretes also included slag filler. The tensile strength increased almost $100 \%$ for mixes BSI and BSII compared to mix BO. 


\section{Author's Personal Copy}
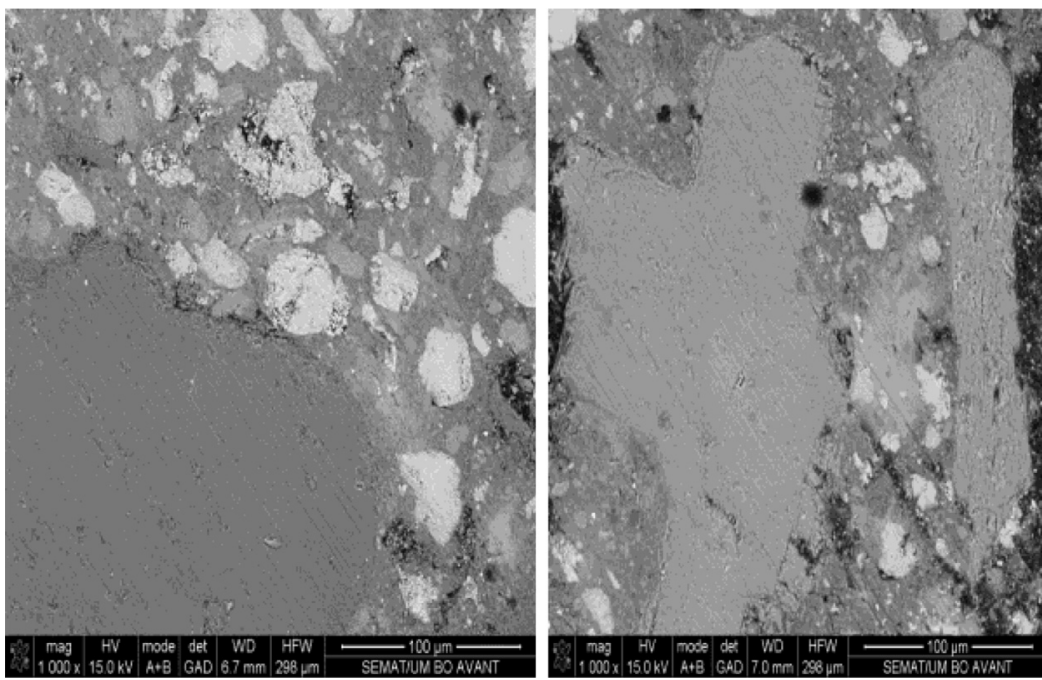

Fig. 6. SEM micrograph showing the structure of the conventional concrete $-\mathrm{BO}(1000 \times)$.
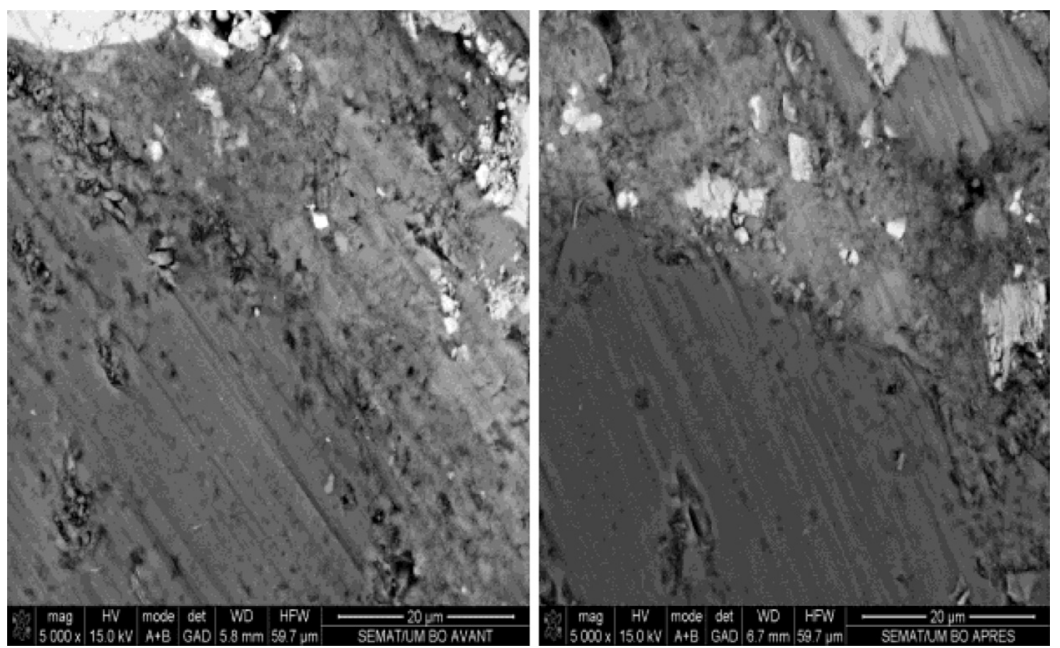

Fig. 7. SEM micrograph showing the structure of the conventional concrete $-\mathrm{BO}(2000 \times)$.
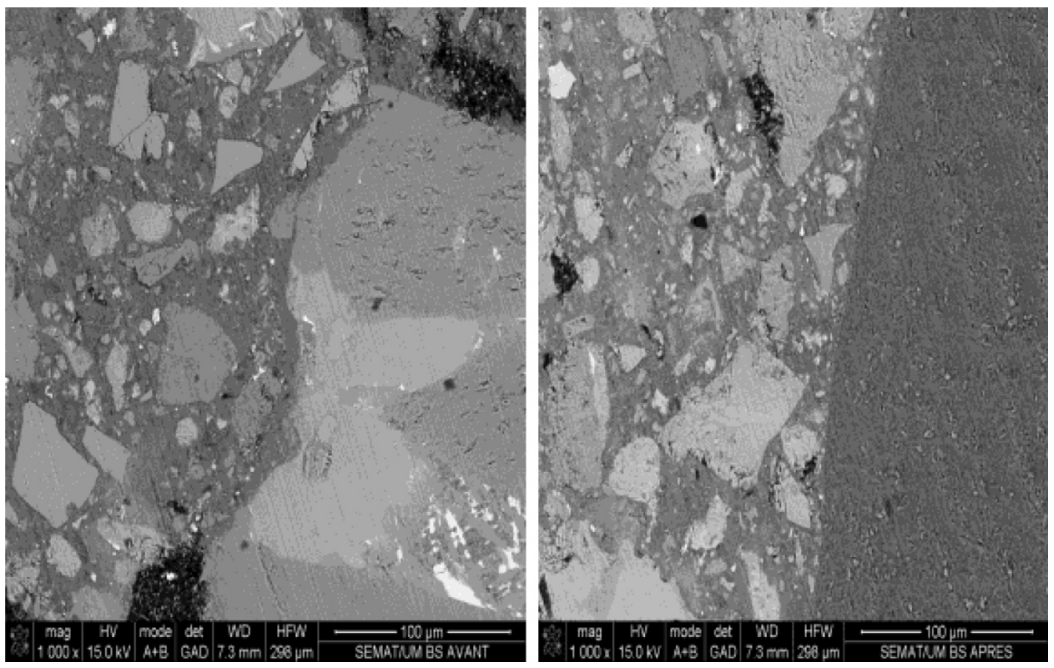

Fig. 8. SEM micrograph showing the structure of concrete BSII $(1000 \times)$. 

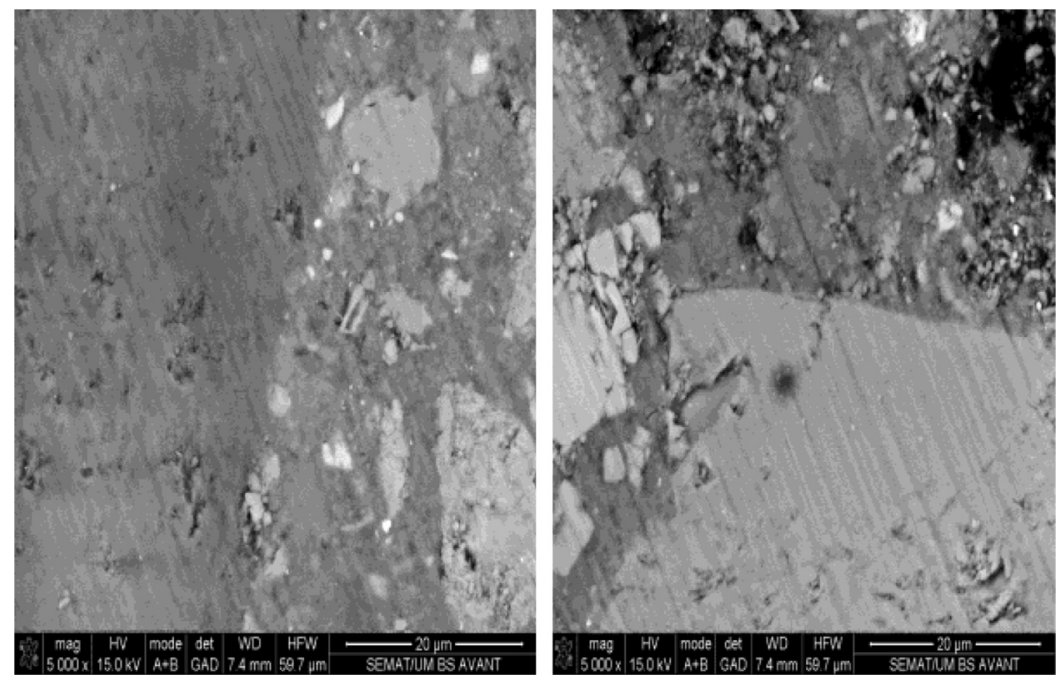

Fig. 9. SEM micrograph showing the structure of concrete BSII $(2000 \times)$.

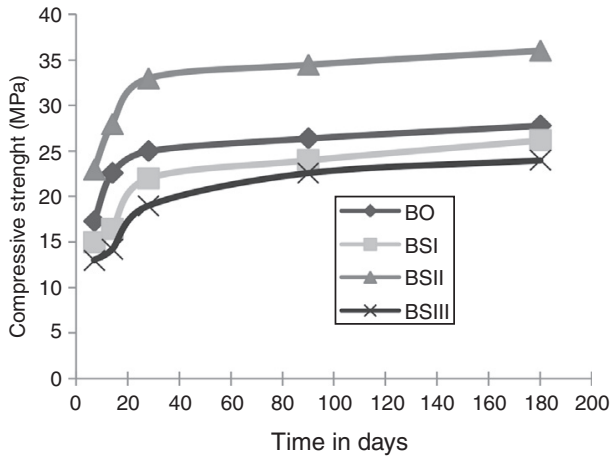

Fig. 10. Compressive strengths of the concretes.

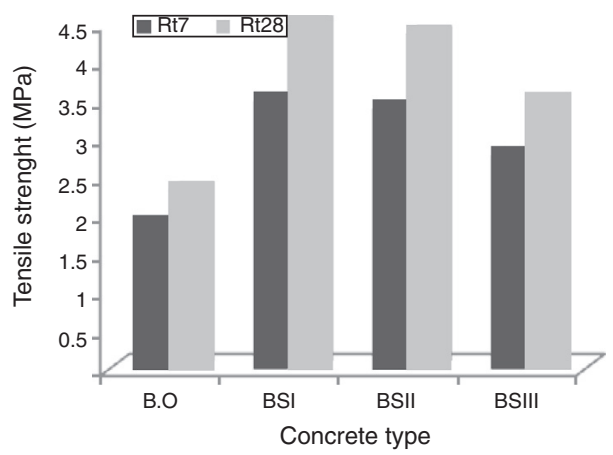

Fig. 11. Tensile strengths of the concretes, at 7 and 28 days.

This can be explained by the pozzolanic effect evidenced by the granulated slag filler.

\subsection{Three points bending strength}

The three points bending test was performed according to ASTM D 790-81 [31]. The bending strengths, shown in Fig. 12, are the average of twelve specimens for each type of concrete. The BSII concrete, with natural sand completely replaced by the slag sand, has the highest bending strength between all the concretes. The BSII concrete also includes slag filler and

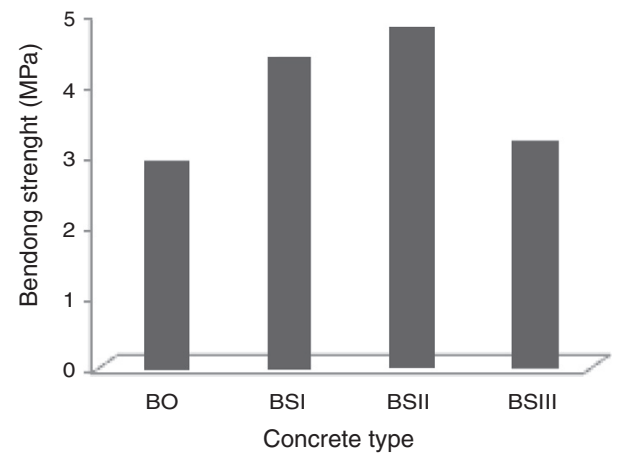

Fig. 12. Bending strengths of the concretes.

super plasticizer, in its composition. The BSII concrete strength growths $59 \%$ compared with the conventional concrete BO. The bending tensile strength mainly depends on the paste/aggregates adhesion, improved by the use of the slag filler and the super plasticizer.

\section{Conclusion}

The concretes with incorporation of blast furnace slag sand represent a new family of construction materials. The respective fields of application depend on the performance, cost and availability of the components. To set performance-based concrete with incorporation of blast furnace slag El-Hadjar, a general characterization was essential. This characterization was made by microstructure analysis and determination of the mechanical properties, like compressive, tensile and bending strengths. The results analyses made possible to conclude several positive points:

- Microstructure modifications at the cement matrices level and at the interface zones were observed. The possible pozzolanicity of the used filler was observed.

- The resistance of the slag concrete comes from the lower porosity compared with the conventional concrete. It can be 
deduced that the compressive strength depends on the nature and strength of the formed hydrates, on their association mode and on the porosity.

- A strength gain was obtained with the incorporation of granulated slag filler and super plasticizer, in the concrete. This was due to the reactivity of this type of filler and the lower water/cement ratio enabled by the super plasticizer.

- The use of granulated slag filler and sand in the concrete manufacturing can have a direct relationship with the concrete cost, minimizing the amount of cement in the concrete composition, and increasing the mechanical characteristics of the concrete.

\section{References}

[1] D. Achoura, Contribution to the Study of the Formulation and Characterization of Concretes Slag Based sand Blast Furnaces El Hadjar (Doctoral thesis), University of Annaba, Algeria, 2005.

[2] B.I. Aguida, Concrete Sand, Optimal Composition and Hydrothermal Effect on its Compressive Strength, Magister Memory, University of Béchar, Algeria, 2007.

[3] SABLOCRETE, Sand Concrete, National research/development project, National School of Bridges and Roads, Paris, France, 1998.

[4] AFNOR, French Standardization Association, Concrete and Concrete Components, vol. 1 and 2, 4th ed., 1995.

[5] AFNOR, French Standardization Association, Concrete and Concrete Constituents (Concrete Test Methods), vol. 2, 5th ed., 2002.

[6] H. Qasrawi, F. Shalabi, I. Asi, Constr. Build. Mater. 23 (2009).

[7] M. Khanzadi, A. Behnood, Constr. Build. Mater. 23 (2009).

[8] S. Marinković, V. Radonjanin, M. Malešev, I. Ignjatović, Waste Manage. 30 (2010).

[9] N. Ferhoune, Thin-Walled Struct. 80 (2014).

[10] N. Ferhoune, J. Zeghiche, Mech. Ind. 16 (2015) 112.

[11] L. Alexandre, J.L. Sebileau, The Blast Furnace Slag, Technical Center and Promotion of Slags, 1988

[12] R. Dupain, L. Anchon, J.C. Saint Aramon, Aggregates, Soils, Cement and Concrete, Characterization of Civil Engineering Materials by Laboratory Tests, Paris, 2004

[13] C. Morrison, R. Hooper, K. Lardner, Cem. Concr. Res. 33 (2003) 12.
[14] N. Robeyst, E. Gruyaert, C.U. Grosse, N. De Belie, Cem. Concr. Res. 38 (2008) 10.

[15] E. Gruyaert, P. Van den Heede, M. Maes, N. De Belie, Cem. Concr. Res. $42(2012) 1$.

[16] N. Mobasher, S.A. Bernal, O.H. Hussain, D.C. Apperley, H. Kinoshita, J.L. Provis, Cem. Concr. Res. 66 (2014).

[17] IANOR, Institut Algérien de Normalisation, NA422, Cement, composition, specifications and compliance criteria for common cements, Alger, Algeria, 2005 .

[18] AFNOR, French Standardization Association, NFP18-404, Concretes, tests of suitability and control, manufacture and preservation of specimens, Paris, France, 1981

[19] AFNOR, French Standardization Association, NF P18-553, Aggregates, Preparation of a test sample, Paris, France, 1978.

[20] AFNOR, French Standardization Association, NF P18-555, Aggregates, Density measurements, sands absorption coefficient and water content, Paris, France, 1990.

[21] AFNOR, French Standardization Association, NF EN 933-8, Tests to determine the geometrical characteristics of aggregates - Part 8: Evaluation of fines - Sand equivalent, Paris, France, 1999.

[22] AFNOR, French Standardization Association, NF P18-560, Aggregates, particle size analysis by sieving, Paris, France, 1990.

[23] AFNOR, French Standardization Association, NF P18-554, Aggregates - Measurement of density, porosity, absorption coefficient and moisture content of chippings and pebbles, Paris, France, 1990.

[24] AFNOR, French Standardization Association, NF P18-573, Aggregates Test of Los Angeles, Paris, France, 1990.

[25] AFNOR, French Standardization Association, NFEN934-2, Adjuvants for concrete, mortar and grout, Part 2: Concrete admixtures, definitions, requirements, confirmation, marking and labeling, Paris, France, 2012.

[26] AFNOR, French Standardization Association, NFP18-451, Concretes Slump test, Paris, France, 1981.

[27] M. Senani, N. Ferhoune, A. Guettala, Alexandria Eng. J. (2016).

[28] AFNOR, French Standardization Association, NF EN 12350-6, Test for fresh concrete, Part 6: Density, Paris, France, 2012.

[29] AFNOR, French Standardization Association, NF P18-406, Concretes Compression tests, Paris France, 1981.

[30] BSI, British Standards Institution, BS 1881, Testing of concrete, Part 117 : Method for determination of tensile splitting strength, London, UK, 1983

[31] ASTM, American Society for Testing and Materials, D790-81, Standard Test Methods for Flexural Properties, 3-point/4-point bend fixture, West Conshohocken, PA, USA, 1981. 